University of Nebraska - Lincoln

DigitalCommons@University of Nebraska - Lincoln

Faculty Papers and Publications in Animal

Science

Animal Science Department

2010

Growth, Body Chemical Composition, and Tissue Deposition

Rates of Nursery Pigs Fed Crystalline or Protein- Bound Lysine

\author{
J. J. Colina \\ University of Nebraska-Lincoln \\ P. S. Miller \\ University of Nebraska-Lincoln, pmiller1@unl.edu
}

A. J. Lewis

University of Nebraska-Lincoln, alewis2@unl.edu

R. L. Fischer

University of Nebraska-Lincoln

R. M. Diedrichsen

University of Nebraska-Lincoln

Follow this and additional works at: https://digitalcommons.unl.edu/animalscifacpub

Part of the Animal Sciences Commons

Colina, J. J.; Miller, P. S.; Lewis, A. J.; Fischer, R. L.; and Diedrichsen, R. M., "Growth, Body Chemical Composition, and Tissue Deposition Rates of Nursery Pigs Fed Crystalline or Protein- Bound Lysine" (2010). Faculty Papers and Publications in Animal Science. 758.

https://digitalcommons.unl.edu/animalscifacpub/758

This Article is brought to you for free and open access by the Animal Science Department at DigitalCommons@University of Nebraska - Lincoln. It has been accepted for inclusion in Faculty Papers and Publications in Animal Science by an authorized administrator of DigitalCommons@University of Nebraska - Lincoln. 


\title{
Growth, Body Chemical Composition, and Tissue Deposition Rates of Nursery Pigs Fed Crystalline or Protein- Bound Lysine ${ }^{1}$
}

\author{
J. J. Colina, ${ }^{2}$ P. S. Miller, ${ }^{3}$ A. J. Lewis, PAS, R. L. Fischer, ${ }^{4}$ PAS, and R. M. Diedrichsen \\ Department of Animal Science, University of Nebraska, Lincoln 68583-0908
}

\begin{abstract}
A 4-wk experiment was conducted to compare the effect of feeding crystalline lysine relative to the lysine from soybean meal (SBM) on growth performance, body chemical composition, and tissue deposition rates in nursery pigs. Thirty-six pigs were used 18 barrows and 18 gilts, $15 \mathrm{~d}$ old; initial $B W$ (mean $\pm S E M)=6.11 \pm 0.11 \mathrm{~kg}$. Six pigs (3 barrows and 3 gilts) were killed at the beginning of the experiment and the remaining pigs were killed at the end of the experiment to determine body chemi-
\end{abstract}

\footnotetext{
${ }^{1}$ A contribution of the University of Nebraska Agricultural Research Division, supported in part by funds provided through the Hatch Act. Mention of a trade name, proprietary products, or company name is for presentation clarity and does not imply endorsement by the authors of the University of Nebraska.

${ }^{2}$ Present address: Facultad de Ciencias Veterinarias, Cátedra de Producción Animal, Universidad Central de Venezuela, Apartado Postal 4563, Maracay 2101, Aragua, Venezuela.

${ }^{3}$ Corresponding author: pmiller1@unl.edu ${ }^{4}$ Present address: Sioux Nation Ag Center, 1812 N. Cliff Ave., Sioux Falls, SD 57103.
}

cal composition and deposition rates of protein, fat, water, ash, and amino acids. Pigs were blocked by sex and $B W$ (3 blocks of barrows and 3 blocks of gilts) and randomly allotted to 1 of 5 dietary treatments. Pigs were individually penned in 2 nursery facilities, and each treatment was replicated 6 times. The dietary treatments consisted of a corn-SBM basal diet (1.05\% lysine) and diets containing either 1.15 or $1.25 \%$ total lysine, which were achieved by adding lysine (0.10 or 0.20\%) from either SBM or L-lysine hydrochloride (crystalline lysine) to the basal diet. Pigs were given ad libitum access to feed during a 28-d period. Blood samples were collected on the last day of the experiment, and plasma was analyzed for urea concentration. Average daily gain, ADFI, and G:F were similar among dietary treatments $(P>0.50)$. Pigs fed diets supplemented with lysine from $S B M$ had greater $(P<$ 0.001) plasma urea concentrations than pigs supplemented with crystalline lysine. Body protein concentration was greatest $(P<0.01)$ in pigs consuming the diet with $0.10 \%$ added lysine from crystalline lysine. However, protein deposition was similar in pigs fed both supplemented diets $(P>0.10)$. Body fat concentration and fat deposition were similar $(P>$ 0.25; $P>0.10)$ in pigs fed diets supplemented with crystalline lysine or lysine from SBM, respectively. Ash concentration was greatest $(P<0.05)$ in pigs fed $0.10 \%$ added crystalline lysine compared with pigs fed added lysine from SBM. Lysine concentration and deposition were similar in pigs fed crystalline lysine and pigs fed SBM-bound lysine. The results suggest there are no differences in growth, body chemical components, and tissue deposition rate between nursery pigs fed SBM-bound lysine and lysine from L-lysine hydrochloride.

Key words: body composition, growth performance, lysine, protein accretion, swine

\section{INTRODUCTION}

Lysine is the first-limiting amino acid (AA) in a low-protein corn and soybean meal (SBM) diet for nursery pigs (Mavromichalis et al., 1998). The efficiency of lysine utilization by pigs can be improved by supplying AA according to growth potential and physiological status (Lenis et al., 1999) or by supplementing low-pro- 
tein diets with crystalline AA (Easter and Baker, 1980; Han and Lee, 2000). However, studies have shown that growing pigs utilize supplements of crystalline lysine in diets fed once daily less efficiently than diets fed ad libitum (Batterham and Bayley, 1989; Yen et al., 2004), which may be explained by the difference in rates of net portal absorption between crystalline and protein-bound lysine (Yen et al., 2004).

Most of the aforementioned research was conducted on growing-finishing pigs without considering the lysine source. Experiments with nursery pigs have been conducted to determine the efficiency of crystalline AA utilization for growth and protein deposition (Sawadogo et al., 1997). Similarly, Cosgrove et al. (1985), in a study with nursery pigs given ad libitum access to feed, reported that crystalline lysine was utilized less efficiently for growth than the protein-bound lysine in SBM. However, little is known about body composition, including $\mathrm{AA}$, and tissue deposition rates in nursery pigs fed ad libitum crystalline or protein-bound lysine. Therefore, the objective of this study was to compare growth performance, body chemical composition, tissue deposition rates, and plasma urea concentrations (PUC) of nursery pigs fed ad libitum with crystalline lysine or the lysine bound to soybeans.

\section{MATERIALS AND METHODS}

\section{Animals, Experimental Design, and Facilities}

All procedures involving animals were approved by the University of Nebraska-Lincoln Institutional Animal Care and Use Committee. Thirty-six crossbred (Landrace $\times$ Yorkshire $\times$ Duroc $\times$ Hampshire) nursery pigs (18 barrows and 18 gilts, weaned at $15 \mathrm{~d}$ of age; initial BW of approximately 6 $\mathrm{kg}$ ) were used. Thirty pigs (15 barrows and 15 gilts) were randomly allotted to dietary treatments in a randomized complete block design with sex and BW as the blocking criteria (3 blocks of barrows and 3 blocks of gilts). The remaining 6 pigs (3 barrows and 3 gilts) were killed to determine initial body composition. Pigs were housed individually in 30 slotted-floor pens in 2 nursery facilities. Each pen was $1.7 \times 2.2 \mathrm{~m}$ with vertical-rod gating and had plasticcoated wire flooring, a nipple waterer, and a 3-hole stainless steel feeder. During the first $2 \mathrm{wk}$, pigs were provided with comfort boards and heat lamps. A recorder was placed in the nurseries to monitor humidity and environmental temperature, which were maintained at approximately $60 \%$ and $25^{\circ} \mathrm{C}$, respectively. Lights remained on $24 \mathrm{~h} / \mathrm{d}$.

\section{Dietary Treatments}

During the first $5 \mathrm{~d}$ after weaning, all pigs were fed the same standard prestarter diet (23.5\% CP, $1.75 \%$ lysine, $0.75 \%$ calcium, and $0.70 \%$ phosphorus, with $165 \mathrm{mg} / \mathrm{kg}$ apramycin sulfate) to allow adaptation to the initial stress of weaning. For the next $28 \mathrm{~d}$, pigs were fed 1 of 5 dietary treatments (Tables 1 and 2). All diets were formulated on a total AA basis (NRC, 1998) to be limiting in lysine (a preliminary experiment had confirmed that lysine was the first-limiting AA in the experimental diets). The basal diet was a cornSBM diet (1.05\% total lysine). Two additional diets were formulated by adding $0.10 \%$ (1.15\% total lysine) and $0.20 \%$ ( $1.25 \%$ total lysine) crystalline lysine (L-lysine hydrochloride), and the remaining 2 diets were supplemented with SBM in amounts that were equal to the lysine concentration in the crystalline lysine diets. Soybean meal and crystalline lysine were added to the basal diet at the expense of cornstarch. Sunflower meal was added to all dietary treatments because of the relatively low lysine concentration. The CP and lysine concentrations in SBM and sunflower meal were determined before formulating the diets. Threonine, methionine, and tryptophan were added to all diets to meet the requirements (NRC, 1998) for these AA. During the experimental period, pigs were allowed ad libitum access to the 5 experimental diets and water.

\section{Data and Sample Collection}

Pigs and feeders were weighed at the beginning of the experiment and every week thereafter to determine ADG, ADFI, and G:F. At the end of the experiment, blood was sampled via jugular venipuncture. Blood samples were collected into heparinized evacuated tubes $(10 \mathrm{~mL}$; Becton, Dickinson and Company, Franklin Lakes, NJ) and placed in ice until centrifugation. On the day of collection, samples were centrifuged at $2,000 \times g$ for $20 \mathrm{~min}$ at room temperature, and plasma was separated and frozen at $-20^{\circ} \mathrm{C}$ until further analysis. Plasma urea concentration was determined using the automated technique of Marsh et al. (1965).

\section{Slaughter Procedures}

Six pigs were killed at the beginning and 30 pigs (6 pigs/treatment; 15 barrows and 15 gilts) were killed at the end of the experiment by injecting an overdose of pentobarbital sodium. Gut contents (any remaining digesta) were removed and the whole body of the pigs (including the gastrointestinal tract) was weighed to obtain empty BW (EBW) and was then frozen at $-20^{\circ} \mathrm{C}$ until further processing. The frozen empty body was ground through a commercial grinder with a 12.5-mm die (Model 1556, Biro, Marblehead, $\mathrm{OH})$. The ground body was thoroughly mixed by hand to ensure homogeneity, and a subsample of approximately $4 \mathrm{~kg}$ was obtained. Subsequently, each sample was ground 3 times using a smaller grinder (Model 5120-0-009, Toledo Scale, Toledo, OH) with successively smaller dies (6.5to 2-mm dies). Samples were mixed thoroughly by hand between each pass through the grinder. During the last mincing, frequent grab samples of approximately $100 \mathrm{~g}$ were taken at random, mixed thoroughly to obtain a total sample of approximately $500 \mathrm{~g}$, placed in plastic bags, and frozen at $-20^{\circ} \mathrm{C}$ until chemical analysis. 
Table 1. Composition of experimental diets ${ }^{1}$

\begin{tabular}{|c|c|c|c|c|c|}
\hline \multirow[b]{3}{*}{ Item } & \multicolumn{5}{|c|}{ Diet $^{2}$} \\
\hline & \multirow{2}{*}{$\begin{array}{c}\text { Basal } \\
1.05 \% \text { lysine }\end{array}$} & \multicolumn{2}{|c|}{ Crystalline } & \multicolumn{2}{|c|}{ Soybean meal } \\
\hline & & $1.15 \%$ lysine & $1.25 \%$ lysine & $1.15 \%$ lysine & $1.25 \%$ lysine \\
\hline \multicolumn{6}{|l|}{ Ingredient, \% } \\
\hline Corn & 32.96 & 32.96 & 32.96 & 32.96 & 32.96 \\
\hline Cornstarch & 7.00 & 6.87 & 6.74 & 3.50 & 0.00 \\
\hline Soybean meal $(46.5 \% \mathrm{CP})$ & 10.00 & 10.00 & 10.00 & 13.50 & 17.00 \\
\hline Spray-dried plasma protein & 4.00 & 4.00 & 4.00 & 4.00 & 4.00 \\
\hline Fishmeal (menhaden) & 4.00 & 4.00 & 4.00 & 4.00 & 4.00 \\
\hline Sunflower meal & 17.50 & 17.50 & 17.50 & 17.50 & 17.50 \\
\hline Lactose & 15.00 & 15.00 & 15.00 & 15.00 & 15.00 \\
\hline Dicalcium phosphate & 1.35 & 1.35 & 1.35 & 1.35 & 1.35 \\
\hline Limestone & 0.15 & 0.15 & 0.15 & 0.15 & 0.15 \\
\hline Corn oil & 5.00 & 5.00 & 5.00 & 5.00 & 5.00 \\
\hline Vitamin premix ${ }^{3}$ & 1.00 & 1.00 & 1.00 & 1.00 & 1.00 \\
\hline Trace mineral premix ${ }^{4}$ & 0.10 & 0.10 & 0.10 & 0.10 & 0.10 \\
\hline Salt & 0.25 & 0.25 & 0.25 & 0.25 & 0.25 \\
\hline Zinc oxide & 0.42 & 0.42 & 0.42 & 0.42 & 0.42 \\
\hline Antibiotic & 1.00 & 1.00 & 1.00 & 1.00 & 1.00 \\
\hline L-Tryptophan & 0.05 & 0.05 & 0.05 & 0.05 & 0.05 \\
\hline L-Threonine & 0.13 & 0.13 & 0.13 & 0.13 & 0.13 \\
\hline DL-Methionine & 0.09 & 0.09 & 0.09 & 0.09 & 0.09 \\
\hline L-Lysine hydrochloride & - & 0.13 & 0.26 & - & - \\
\hline \multicolumn{6}{|l|}{ Calculated nutrient composition } \\
\hline $\mathrm{CP}, 5 \%$ & 18.93 & 19.13 & 19.98 & 20.70 & 22.90 \\
\hline Lysine, \% & 1.05 & 1.15 & 1.25 & 1.15 & 1.25 \\
\hline Calcium, \% & 0.90 & 0.90 & 0.90 & 0.91 & 0.92 \\
\hline Phosphorus, \% & 0.71 & 0.71 & 0.71 & 0.72 & 0.74 \\
\hline $\mathrm{ME}, \mathrm{kcal} / \mathrm{kg}$ & 3,269 & 3,264 & 3,259 & 3,241 & 3,213 \\
\hline
\end{tabular}

${ }^{1}$ As-fed basis.

2Basal: Iysine concentration provided by corn, soybean meal, menhaden fishmeal, spray-dried plasma protein, and sunflower meal; crystalline: basal diet supplemented with 0.13 and $0.26 \%$ lysine from L-lysine hydrochloride ( $78 \%$ lysine); soybean meal: basal diet supplemented with 3.50 and $7.00 \%$ soybean meal.

${ }^{3}$ Supplied per kilogram of diet: vitamin A (as retinyl acetate), 3,088 IU; vitamin D (as cholecalciferol), 386 IU; vitamin E (as a-tocopheryl acetate), $15 \mathrm{IU}$; menadione, $2.3 \mathrm{mg}$; riboflavin, $3.9 \mathrm{mg}$; D-pantothenic acid, $15.4 \mathrm{mg}$; niacin, $23.2 \mathrm{mg}$; choline, $77.2 \mathrm{mg}$; cyanocobalamin (vitamin $\mathrm{B}_{12}$ ), $15.4 \mu \mathrm{g}$.

${ }^{4}$ Supplied per kilogram of diet: copper (as CuSO $\cdot 5 \mathrm{H}_{2} \mathrm{O}$ ), $11 \mathrm{mg}$; iodine [as $\mathrm{Ca}\left(\mathrm{IO}_{3}\right) \cdot \mathrm{H}_{2} \mathrm{O}$ ], $0.22 \mathrm{mg}$; zinc (as $\left.\mathrm{ZnO}\right), 110 \mathrm{mg}$; iron (as $\mathrm{FeSO}_{4} \cdot \mathrm{H}_{2} \mathrm{O}$ ), $110 \mathrm{mg}$; manganese (as $\mathrm{MnO}$ ), $22 \mathrm{mg}$; selenium (as $\mathrm{Na}_{2} \mathrm{SeO}_{3}$ ), $0.3 \mathrm{mg}$.

${ }^{5}$ Analyzed composition.

\section{Chemical Analysis}

Diet samples were ground through a 1-mm screen (Tecator Cyclotec 1093 Sample Mill, Foss Tecator, Höganäs, Sweden) and analyzed for CP and AA. The whole-body samples were analyzed for DM, CP, fat, ash, and AA. Duplicate whole-body subsamples (approximately $4 \mathrm{~g}$ each) were freeze-dried to determine DM content. Crude protein $(\mathrm{N} \times 6.25)$ was determined on wet samples with a Kjeltec apparatus (Foss North America, Eden Praire, MN) according to AOAC (1998) procedures. Fat was determined on freeze-dried samples by an 8-h extraction using the Goldfisch extraction procedure described by AOAC (1998). Ash was determined by burning the wet samples in a muffle furnace at $550^{\circ} \mathrm{C}$ for $8 \mathrm{~h}$. Amino acid composition was determined on fatfree dried samples that were ground through a 1-mm screen to obtain a powdery sample before analysis. To determine AA composition, diets and whole-body samples were hydrolyzed for $20 \mathrm{~h}$ (6 N hydrochloric acid) at $110^{\circ} \mathrm{C}$ (Moore and Stein, 1963). Amino acids were separated using ion-exchange chromatography. The AA analyzer contained a cation exchange column and AA were eluted by a gradient of lithium buffers. After elution from the column, the AA were quantified fluorometrically using $o$-phthalaldehyde as the derivatization reagent. Sulfur-containing AA (methi- 
Table 2. Analyzed amino acid composition of diets (\%)

\begin{tabular}{|c|c|c|c|c|c|}
\hline \multirow[b]{3}{*}{ Item } & \multicolumn{5}{|c|}{ Diet $^{1}$} \\
\hline & \multirow{2}{*}{$\begin{array}{c}\text { Basal } \\
1.05 \% \text { lysine }\end{array}$} & \multicolumn{2}{|c|}{ Crystalline } & \multicolumn{2}{|c|}{ Soybean meal } \\
\hline & & $1.15 \%$ lysine & $1.25 \%$ lysine & $1.15 \%$ lysine & $1.25 \%$ lysine \\
\hline \multicolumn{6}{|l|}{ Amino acid } \\
\hline Arginine & 1.12 & 1.18 & 1.16 & 1.25 & 1.39 \\
\hline Histidine & 0.44 & 0.43 & 0.43 & 0.46 & 0.52 \\
\hline Isoleucine & 0.73 & 0.74 & 0.74 & 0.75 & 0.80 \\
\hline Leucine & 1.41 & 1.43 & 1.43 & 1.51 & 1.70 \\
\hline Lysine & 0.93 & 1.05 & 1.16 & 1.03 & 1.15 \\
\hline Methionine + cysteine & 0.80 & 0.81 & 0.79 & 0.85 & 0.89 \\
\hline Phenylalanine + tyrosine & 1.30 & 1.34 & 1.33 & 1.40 & 1.60 \\
\hline Threonine & 0.98 & 0.95 & 0.97 & 1.05 & 1.09 \\
\hline Tryptophan² (calculated) & 0.28 & 0.28 & 0.28 & 0.30 & 0.32 \\
\hline Valine & 0.90 & 0.91 & 0.91 & 1.00 & 1.11 \\
\hline \multicolumn{6}{|c|}{ Analyzed amino acid ratios relative to lysine ${ }^{3}$} \\
\hline Arginine & 120 & 112 & 100 & 121 & 121 \\
\hline Histidine & 47 & 41 & 37 & 45 & 45 \\
\hline Isoleucine & 79 & 70 & 64 & 73 & 70 \\
\hline Leucine & 152 & 136 & 123 & 147 & 148 \\
\hline Methionine + cysteine & 86 & 77 & 68 & 83 & 77 \\
\hline Phenylalanine + tyrosine & 140 & 128 & 115 & 136 & 139 \\
\hline Threonine & 105 & 90 & 84 & 102 & 95 \\
\hline Tryptophan² (calculated) & 30 & 27 & 24 & 29 & 28 \\
\hline Valine & 97 & 87 & 78 & 97 & 97 \\
\hline
\end{tabular}

${ }^{1}$ Lysine values are calculated.

${ }^{2}$ Tryptophan was not analyzed in this experiment.

${ }^{3}$ Lysine $=100$.

onine and cysteine) were determined by ion-exchange chromatography of acid hydrolysate samples that had been preoxidized with performic acid (AOAC, 1998).

\section{Calculations}

Initial EBW and chemical body composition of pigs slaughtered initially were used to estimate the initial EBW and body chemical composition of pigs slaughtered at the end of the experiment. Deposition rates of water, $\mathrm{CP}$, fat, ash, and AA in the whole body were estimated as the difference between the total weight of chemical components at the end and at the beginning of the experiment divided by the number of experimental days (Gómez et al., 2002).

\section{Statistical Analysis}

Data for growth variables (ADFI, ADG, and G:F) were analyzed as a randomized complete block design (6 blocks) with repeated measurements in time by using the MIXED procedure (SAS Institute Inc., Cary, NC). Data for PUC, whole-body chemical components, and tissue deposition rates were analyzed as a randomized complete block design. The individual pig was considered the experimental unit for all variables. Linear contrasts were used to compare the 5 dietary treatments. The linear contrasts evaluated were the basal diet versus the others and crystalline lysine versus SBM lysine at each total lysine concentration (1.15 and 1.25\% lysine). Because sex did not affect any of the variables studied, it was not included in the model and data from barrows and gilts were pooled.
The following model was used for growth variables:

$$
\begin{aligned}
& \mathrm{Y}_{\mathrm{ijkl}}=\mu+\mathrm{B}_{\mathrm{i}}+\mathrm{D}_{\mathrm{j}}+\mathrm{W}_{\mathrm{k}} \\
& \quad+(\mathrm{D} \times \mathrm{W})_{\mathrm{jk}}+\mathrm{E}_{\mathrm{ijk},}
\end{aligned}
$$

where $Y_{i j k l}$ is the observation on the ith block, jth diet, kth week, and lth replication; $\mu$ is the overall mean; $B_{i}$ is the random block effect $(\mathrm{i}=1, \ldots$, $6)$; $\mathrm{D}_{\mathrm{j}}$ is the diet effect $(\mathrm{j}=1, \ldots, 5)$; $\mathrm{W}_{\mathrm{k}}$ is the week effect $(\mathrm{k}=1, \ldots, 4)$; $(\mathrm{D} \times \mathrm{W})_{\mathrm{jk}}$ is the diet $\times$ week effect; and $\mathrm{E}_{\mathrm{iik}}$ is the random residual error. The following model was used for PUC, whole-body chemical components, and tissue deposition rates:

$$
\mathrm{Y}_{\mathrm{ijk}}=\mu+\mathrm{B}_{\mathrm{i}}+\mathrm{D}_{\mathrm{j}}+\mathrm{E}_{\mathrm{ijk}} \text {, }
$$

where $Y_{i j k}$ is the observation on the ith block, jth diet, and kth replication; $\mu$ is the overall mean; $B_{i}$ is the random block effect $(\mathrm{i}=1, \ldots, 6) ; \mathrm{D}_{\mathrm{j}}$ 
Table 3. Performance and lysine intake of pigs fed lysine-limiting diets at 3 different concentrations

\begin{tabular}{|c|c|c|c|c|c|c|c|c|c|c|c|}
\hline \multirow[b]{3}{*}{ Item ${ }^{1}$} & \multicolumn{6}{|c|}{ Diet $^{2}$} & \multicolumn{5}{|c|}{$P$-value } \\
\hline & \multirow{2}{*}{$\begin{array}{l}\text { Basal } \\
1.05 \% \\
\text { lysine }\end{array}$} & \multicolumn{2}{|c|}{ Crystalline } & \multicolumn{2}{|c|}{ Soybean meal } & \multirow[b]{2}{*}{ SEM } & \multirow[b]{2}{*}{ Diet } & \multicolumn{4}{|c|}{ Contrast $^{3}$} \\
\hline & & $\begin{array}{l}1.15 \% \\
\text { lysine }\end{array}$ & $\begin{array}{l}1.25 \% \\
\text { lysine }\end{array}$ & $\begin{array}{l}1.15 \% \\
\text { lysine }\end{array}$ & $\begin{array}{l}1.25 \% \\
\text { lysine }\end{array}$ & & & 1 & 2 & 3 & L \\
\hline Initial BW, kg & 6.10 & 6.13 & 6.02 & 6.17 & 6.12 & 0.11 & 0.90 & - & - & - & - \\
\hline Final BW, kg & 21.32 & 21.72 & 20.69 & 22.19 & 22.14 & 0.75 & 0.60 & - & - & - & - \\
\hline ADG, $g$ & 544 & 560 & 546 & 572 & 572 & 25.63 & 0.85 & - & - & - & - \\
\hline ADFI, $g$ & 849 & 860 & 816 & 881 & 883 & 41.98 & 6.66 & - & - & - & - \\
\hline $\mathrm{G}: \mathrm{F}, \mathrm{g} / \mathrm{g}$ & 0.67 & 0.68 & 0.70 & 0.68 & 0.68 & 0.02 & 0.85 & - & - & - & - \\
\hline $\begin{array}{l}\text { Plasma urea, } \\
\text { mg/100 mL }\end{array}$ & 29.72 & 26.26 & 30.64 & 37.42 & 38.00 & 2.59 & $<0.01$ & 0.28 & $<0.01$ & $<0.01$ & $<0.01$ \\
\hline
\end{tabular}

${ }^{1}$ Mean from 6 pigs (3 barrows and 3 gilts).

${ }^{2}$ Basal: lysine concentration provided by corn, soybean meal, menhaden fishmeal, spray-dried plasma protein, and sunflower meal; crystalline: diets supplemented with 0.13 and $0.26 \%$ lysine from L-lysine hydrochloride ( $278 \%$ lysine); soybean meal: diets supplemented with 3.50 and $7.00 \%$ soybean meal.

${ }^{3}$ Contrasts: 1 = basal versus others; 2 = crystalline versus soybean meal $(1.15 \%$ lysine $) ; 3=$ crystalline versus soybean meal $(1.25 \%$ lysine); $L$ = linear effect of lysine concentration.

is the diet effect $(\mathrm{j}=1, \ldots, 5)$; and $\mathrm{E}_{\mathrm{ij \textrm {k }}}$ is the random residual error.

\section{RESULTS AND DISCUSSION}

\section{Growth Performance}

Initial BW, final BW, ADG, ADFI, and G:F (Table 3) were similar in pigs fed the diets supplemented with crystalline lysine and lysine from SBM at the same lysine concentration $(P>0.50)$. In fact, ADG numerically decreased with increasing dietary lysine $(0.20 \%)$ from the crystalline source and was similar for both diets supplemented with lysine from SBM. In contrast to the present study, Cosgrove et al. (1985), Leibholz (1986), and Adeola et al., (1994) reported a linear response in ADG when feeding nursery pigs graded concentrations of supplemental dietary lysine from crystalline lysine or protein-bound lysine in SBM.

Overall, the results of this research indicate that when pigs are allowed ad libitum access to feed, the growth performance of pigs fed a diet supplemented with crystalline lysine or lysine from SBM would be the same. Similar to the results reported herein, other studies with pigs given ad libitum access to feed (Leibholz, 1986; Gahl et al., 1994; Leibert, 1995) have not reported any differences in the growth performance of pigs fed crystalline lysine or lysine from SBM. In contrast, results from this study are not really comparable with those of Pollmann et al. (1984), who found that 5- to 17-kg pigs fed SBM had improved ADG and feed efficiency compared with those fed diets that contained free lysine as L-lysine hydrochloride.

\section{Plasma Urea Concentration}

Plasma urea concentration (Table 3) increased with increasing lysine supplementation ( 0.10 or $0.20 \%$ lysine; linear effect, $P<0.01)$. Although there was a numerical decrease in PUC when $0.10 \%$ crystalline lysine was added, with respect to the basal diet, this difference was not significant $(P=0.28)$. Overall, pigs fed diets supplemented with lysine from SBM had greater $(P<0.001)$ PUC than pigs fed diets supplemented with crystalline lysine. The lower concentrations of PUC for pigs fed diets supplemented with L-lysine hydrochloride support the view that these diets had lower CP densities than the
SBM diets. As a result of the greater protein content and the excess of AA (other than lysine), PUC increased via increased urea synthesis (Rosebrough et al., 1983; Cai et al., 1996).

\section{Body Composition and Deposition Rates}

Empty BW and whole-body chemical composition of pigs slaughtered at the beginning of the experimental period are shown in Table 4. Because the means for body composition variables were similar in barrows and gilts, the means were pooled. The proportion of EBW to initial BW was $95 \%$, and the total of the chemical components was $98 \%$ of the whole body. The whole-body chemical composition of pigs slaughtered at the beginning of the experiment was similar to the composition reported by Shields et al. (1983) for nursery pigs (6 to $18 \mathrm{~kg}$ EBW). Water and protein concentrations of pigs slaughtered at the beginning of the experiment were also similar to the values reported by Whittemore et al. (1981). However, fat concentration was lower than that of pigs with similar BW in previous reports (Whittemore et al., 1981; Shields et al., 1983). These dif- 
ferences may be related to differences in genetic potential for fat and lean deposition.

Body chemical composition and deposition rates of pigs slaughtered at the end of the experiment are shown in Table 5. Final EBW was similar $(P=0.64)$ among dietary treatments. The proportion of EBW to final BW ranged from 94 to $95 \%$, which indicates that approximately $5 \%$ of the weight was gastrointestinal contents, which is in agreement with the results of Shields et al. (1983). Body protein concentration was affected $(P<0.01)$ by dietary lysine concentration. At $0.10 \%$ added dietary lysine, pigs fed the diets supplemented with crystalline lysine had greater $(P<0.01)$ body protein concentrations than pigs fed the diets supplemented with lysine from SBM. However, at $0.20 \%$ added dietary lysine, both groups of pigs had similar $(P=0.70)$ protein concentrations. Whole-body protein content was similar to values estimated by Campbell (1977) and Shields et al. (1983). Body protein deposition rates were similar $(P=0.35)$ among treatments. Protein deposition rates were greater than the values reported by Campbell (1977) and Adeola (1995) in nursery pigs because the researchers measured protein deposition in carcass only. However, Campbell et al. (1988) measured protein deposition in the EBW of 8 - to $20-\mathrm{kg}$ pigs and the reported values are within the range estimated in the present study.

Gahl et al. (1994), Adeola (1995), and Möhn et al. (2000) reported that the response of body protein deposition to increasing dietary AA supply is typically linear when the firstlimiting $\mathrm{AA}$ is deficient in the diet. In our study, ADFI and ADG decreased by 46 and $14 \mathrm{~g} / \mathrm{d}$, respectively, in pigs fed $0.20 \%$ added L-lysine hydrochloride compared with those fed $0.10 \%$ added lysine from the same lysine source. This lower feed intake and BW gain may be accounted for by the concomitant decrease in protein deposition. Results of the research of Susenbeth et al. (1991) conducted with growing pigs are in agreement with the similar protein deposition in pigs fed diets supplemented with crystalline lysine or lysine from SBM.

Body fat concentration was affected $(P=0.05)$ by dietary lysine concentration but was similar $(P=0.27)$ between the 2 groups of pigs fed diets supplemented with crystalline lysine or lysine from SBM. Deposition rate of body fat tended to decrease as dietary lysine concentration increased within sources $(P=0.09)$, but was similar between sources. These results indicate that fat deposition was not uniquely affected by feeding nursery pigs diets with crystalline lysine or lysine from SBM. Values for body fat concentration and rate of fat deposition are close to those reported by Campbell (1977). In contrast to the present study, Adeola (1995) reported a trend toward an increase in fat content in nursery pig carcasses as the dietary lysine concentration increased from 6 to $8 \mathrm{~g} / \mathrm{kg}$. However, in the aforementioned study, fat deposition was not affected by dietary lysine (intake or concentration). The decreases in body fat deposition in our study were due to the decrease in fat concentration because final EBW were similar among pigs fed the dietary treatments.

Ash concentration was greatest $(P$ $=0.05)$ in pigs fed $0.10 \%$ added crystalline lysine versus lysine from SBM at the same concentration. No differences $(P=0.47)$ were observed for ash deposition and body water concentration or deposition $(P>0.35)$ among diets, with values similar to those reported by Shields et al. (1983) and Campbell et al. (1988). Several researchers (de Lange et al., 2001; Gómez et al., 2002) have indicated that the proportions of body protein, water, and ash are relatively constant and are not affected by diet.

Whole-body essential AA concentrations (Table 6) and deposition rates (Table 7) were similar $(P>0.20)$ among treatments and between the diets supplemented with crystalline lysine and lysine from SBM at the same lysine concentrations. Body lysine concentration $(48 \mathrm{~g} / \mathrm{kg})$ and daily lysine deposition were similar $(P>0.45)$ when comparing the 2

\begin{tabular}{|c|c|c|}
\hline Item & Mean $^{1}$ & SEM \\
\hline Initial BW, kg & 6.19 & 0.29 \\
\hline Empty BW, kg & 5.87 & 0.29 \\
\hline \multicolumn{3}{|l|}{$\begin{array}{l}\text { Body composition, } \\
\mathrm{g} / \mathrm{kg}\end{array}$} \\
\hline Water & 709 & 3.84 \\
\hline Fat & 105 & 3.86 \\
\hline Ash & 24 & 0.48 \\
\hline Protein & 141 & 0.74 \\
\hline \multicolumn{3}{|l|}{ Amino acid, g/kg } \\
\hline Arginine & 47 & 0.39 \\
\hline Histidine & 16 & 0.26 \\
\hline Isoleucine & 20 & 0.07 \\
\hline Leucine & 49 & 0.28 \\
\hline Lysine & 43 & 0.35 \\
\hline $\begin{array}{l}\text { Methionine + } \\
\text { cysteine }\end{array}$ & 23 & 0.05 \\
\hline $\begin{array}{l}\text { Pheylalanine + } \\
\text { tyrosine }\end{array}$ & 43 & 0.42 \\
\hline Threonine & 29 & 0.08 \\
\hline Valine & 29 & 0.09 \\
\hline Alanine & 46 & 0.26 \\
\hline Aspartic acid & 59 & 0.29 \\
\hline Glutamic acid & 93 & 0.35 \\
\hline Glycine & 63 & 0.80 \\
\hline Serine & 30 & 0.26 \\
\hline
\end{tabular}

${ }^{1}$ Mean from 6 pigs, 3 barrows and 3 gilts.

sources of lysine (crystalline lysine: $5.29 \mathrm{~g} / \mathrm{d}$; SBM lysine: $5.32 \mathrm{~g} / \mathrm{d}$ ). Gahl et al. (1992) reported that adding $\mathrm{SBM}$ or $\mathrm{SBM}+$ crystalline lysine to swine diets did not affect body AA composition. Lysine concentrations in whole-body protein were lower than the estimates of 5.45 to $7.3 \mathrm{~g} / 100 \mathrm{~g}$ of protein that have been reported previously (Campbell et al., 1988; Batterham et al., 1990; Mahan and Shields, 1998). This difference from other research is likely unrelated to the age of the pigs used in the present study because it is assumed that nursery and growing pigs have the same amount of lysine per $100 \mathrm{~g}$ of protein.

Unfortunately, there is little published data documenting lysine deposition in nursery pigs. Adeola (1995) reported that lysine deposition was a linear function of lysine intake, 
Table 5. Whole-body chemical composition and deposition rates of pigs slaughtered at the end of the experiment

\begin{tabular}{|c|c|c|c|c|c|c|c|c|c|}
\hline \multirow[b]{3}{*}{ Item $^{1}$} & \multicolumn{6}{|c|}{ Diet $^{2}$} & \multicolumn{3}{|c|}{$P$-value } \\
\hline & \multirow{2}{*}{$\begin{array}{l}\text { Basal } \\
1.05 \% \\
\text { lysine } \\
\end{array}$} & \multicolumn{2}{|c|}{ Crystalline } & \multicolumn{2}{|c|}{ Soybean meal } & \multirow[b]{2}{*}{ SEM } & \multirow[b]{2}{*}{ Diet } & \multicolumn{2}{|c|}{ Contrast $^{3}$} \\
\hline & & $\begin{array}{l}1.15 \% \\
\text { lysine }\end{array}$ & $\begin{array}{l}1.25 \% \\
\text { lysine }\end{array}$ & $\begin{array}{l}1.15 \% \\
\text { lysine }\end{array}$ & $\begin{array}{l}1.25 \% \\
\text { lysine }\end{array}$ & & & 1 & 2 \\
\hline Initial empty BW, kg & 5.77 & 5.81 & 5.71 & 5.84 & 5.80 & 0.10 & 0.90 & - & - \\
\hline Final empty BW, kg & 20.20 & 20.80 & 19.60 & 20.87 & 20.82 & 0.70 & 0.64 & - & - \\
\hline \multicolumn{10}{|c|}{ Body composition, $\mathrm{g} / \mathrm{kg}$} \\
\hline Protein & 151 & 159 & 160 & 147 & 159 & 2.37 & $<0.01$ & $<0.10$ & $<0.01$ \\
\hline Fat & 136 & 131 & 121 & 137 & 127 & 5.09 & 0.05 & 0.12 & 0.27 \\
\hline Water & 668 & 669 & 678 & 672 & 674 & 4.88 & 0.35 & - & - \\
\hline Ash & 26 & 27 & 25 & 24 & 25 & 0.75 & 0.10 & 0.23 & 0.05 \\
\hline \multicolumn{10}{|l|}{ Deposition rate, $\mathrm{g} / \mathrm{d}$} \\
\hline Protein & 80 & 89 & 83 & 81 & 89 & 4.38 & 0.35 & - & - \\
\hline Lysine & 5.07 & 5.33 & 5.23 & 5.10 & 5.55 & 0.30 & 0.61 & - & - \\
\hline Fat & 77 & 75 & 63 & 81 & 72 & 5.84 & 0.09 & 0.45 & 0.37 \\
\hline Water & 336 & 349 & 330 & 352 & 354 & 16.20 & 0.76 & - & - \\
\hline Ash & 14 & 15 & 12 & 13 & 13 & 0.99 & 0.47 & - & - \\
\hline
\end{tabular}

${ }^{1}$ Mean from 6 pigs slaughtered at the beginning of the experiment.

2Basal: lysine concentration provided by corn, soybean meal, menhaden fishmeal, spray-dried plasma protein, and sunflower meal; crystalline: diets supplemented with 0.13 and $0.26 \%$ lysine from L-lysine hydrochloride ( $78 \%$ lysine); soybean meal: diets supplemented with 3.50 and $7.00 \%$ soybean meal.

${ }^{3}$ Contrasts: 1 = basal versus others; 2 = crystalline versus soybean meal $(1.15 \%$ lysine $)$.

Table 6. Empty body essential and nonessential amino acids of pigs slaughtered at the end of the experiment

\begin{tabular}{|c|c|c|c|c|c|c|}
\hline \multirow[b]{3}{*}{ Amino acid, $\mathrm{g} / \mathrm{kg}$} & \multicolumn{5}{|c|}{ Diet $^{1}$} & \multirow[b]{3}{*}{ SEM } \\
\hline & \multirow{2}{*}{$\frac{\text { Basal }}{1.05 \% \text { lysine }}$} & \multicolumn{2}{|c|}{ Crystalline } & \multicolumn{2}{|c|}{ Soybean meal } & \\
\hline & & $1.15 \%$ lysine & $1.25 \%$ lysine & $1.15 \%$ lysine & $1.25 \%$ lysine & \\
\hline Arginine & 48 & 47 & 48 & 48 & 48 & 0.42 \\
\hline Histidine & 18 & 18 & 18 & 19 & 19 & 0.28 \\
\hline Isoleucine & 22 & 22 & 23 & 22 & 23 & 0.25 \\
\hline Leucine & 52 & 52 & 53 & 53 & 54 & 0.50 \\
\hline Lysine & 48 & 47 & 49 & 48 & 49 & 0.70 \\
\hline Methionine + cysteine & 24 & 24 & 24 & 24 & 24 & 0.22 \\
\hline Phenylalanine + tyrosine & 45 & 45 & 47 & 46 & 47 & 0.24 \\
\hline Threonine & 30 & 30 & 31 & 31 & 31 & 0.34 \\
\hline Valine & 30 & 30 & 31 & 30 & 31 & 0.28 \\
\hline Alanine & 48 & 47 & 47 & 47 & 48 & 0.50 \\
\hline Asparagine & 63 & 63 & 64 & 63 & 65 & 0.59 \\
\hline Glutamic acid & 97 & 96 & 98 & 98 & 99 & 0.92 \\
\hline Glycine & 64 & 62 & 62 & 64 & 63 & 0.95 \\
\hline Serine & 31 & 30 & 31 & 31 & 31 & 0.33 \\
\hline
\end{tabular}

${ }^{1}$ Basal: Iysine concentration provided by corn, soybean meal, menhaden fishmeal, spray-dried plasma protein, and sunflower meal; crystalline: diets supplemented with 0.13 and $0.26 \%$ lysine from L-lysine hydrochloride ( $78 \%$ lysine); soybean meal: diets supplemented with 3.50 and $7.00 \%$ soybean meal. 
Table 7. Empty body protein essential amino acid deposition of pigs slaughtered at the end of the experiment

\begin{tabular}{|c|c|c|c|c|c|c|}
\hline \multirow[b]{3}{*}{ Amino acid, g/d } & \multicolumn{5}{|c|}{$\operatorname{Diet}^{1}$} & \multirow[b]{3}{*}{ SEM } \\
\hline & \multirow{2}{*}{$\frac{\text { Basal }}{1.05 \% \text { lysine }}$} & \multicolumn{2}{|c|}{ Crystalline } & \multicolumn{2}{|c|}{ Soybean meal } & \\
\hline & & $1.15 \%$ lysine & $1.25 \%$ lysine & $1.15 \%$ lysine & $1.25 \%$ lysine & \\
\hline Arginine & 4.93 & 5.24 & 4.92 & 5.00 & 5.32 & 0.29 \\
\hline Histidine & 1.94 & 2.07 & 1.94 & 2.05 & 2.17 & 0.12 \\
\hline Isoleucine & 2.27 & 2.46 & 2.40 & 2.34 & 2.56 & 0.13 \\
\hline Leucine & 5.40 & 5.82 & 5.55 & 5.58 & 6.05 & 0.33 \\
\hline Lysine & 5.07 & 5.33 & 5.23 & 5.10 & 5.55 & 0.30 \\
\hline Methionine + cysteine & 2.44 & 2.64 & 2.54 & 2.45 & 2.71 & 0.09 \\
\hline Phenylalanine + tyrosine & 4.75 & 5.06 & 4.91 & 4.92 & 5.31 & 0.17 \\
\hline Threonine & 3.16 & 3.40 & 3.31 & 3.23 & 3.53 & 0.20 \\
\hline Valine & 3.10 & 3.35 & 3.20 & 3.21 & 3.51 & 0.19 \\
\hline Alanine & 4.94 & 5.24 & 4.82 & 4.97 & 5.35 & 0.29 \\
\hline Aspartic acid & 6.58 & 7.02 & 6.68 & 6.67 & 7.31 & 0.41 \\
\hline Glutamic acid & 10.13 & 10.78 & 10.28 & 10.30 & 11.11 & 0.63 \\
\hline Glycine & 6.52 & 6.74 & 6.15 & 6.56 & 6.89 & 0.38 \\
\hline Serine & 3.16 & 3.38 & 3.18 & 3.25 & 3.48 & 0.20 \\
\hline
\end{tabular}

${ }^{1}$ Basal: lysine concentration provided by corn, soybean meal, menhaden fishmeal, spray-dried plasma protein, and sunflower meal; crystalline: diets supplemented with 0.13 and $0.26 \%$ lysine from L-lysine hydrochloride ( $78 \%$ lysine); soybean meal: diets supplemented with 3.50 and $7.00 \%$ soybean meal.

but in our study, lysine deposition rate was not affected by diet. Lysine deposition rates were greater than those reported by Adeola (1995; 2.1 to $4.2 \mathrm{~g} / \mathrm{d}$ ), but were less than those reported by Bikker et al. (1994; 6.6 $\mathrm{g} / \mathrm{d}$ ). In the present study, however, lysine deposition was measured in the whole body, whereas in the study by Adeola (1995), it was measured in the carcass only. Bikker et al. (1994) used pigs within a BW range of 20 to 45 $\mathrm{kg}$, which may account for the higher values. The additional lysine supplied from L-lysine hydrochloride or SBM did not affect the total lysine content in body protein.

The AA concentrations in body protein were lower than those reported by others (Campbell et al., 1988; Batterham et al., 1990). Data are lacking on the deposition rates of AA other than lysine in nursery pigs when comparing crystalline or protein-bound lysine. However, it is evident that concentrations or deposition rates of other essential AA were not affected in pigs fed diets supplemented with crystalline lysine or lysine from SBM. This illustrates that the ratio of these $\mathrm{AA}$ in the body protein relative to lysine is likely not affected by the lysine source. Campbell et al. (1988) and Adeola (1995) reported significant differences in the concentrations of other essential AA as dietary lysine increased; however, these changes were small.

\section{IMPLICATIONS}

Nursery diets can be supplemented with crystalline lysine without affecting body growth and production criteria. The decision to replace SBM with crystalline lysine (and other synthetic AA) will depend on price, lysine concentration, and the concentration of other nutrients.

\section{LITERATURE CITED}

Adeola, O. 1995. Dietary lysine and threonine utilization by young pigs: Efficiency for carcass growth. Can. J. Anim. Sci. 75:445.

Adeola, O., B. V. Lawrence, and T. R. Cline. 1994. Availability of amino acids for 10- to 20 kilogram pigs: Lysine and threonine in soybean meal. J. Anim. Sci. 72:2061.

AOAC. 1998. Official Methods of Analysis. 16th ed. Assoc. Off. Anal. Chem., Arlington, VA.
Batterham, E. S., L. M. Andersen, D. R. Baigent, and E. White. 1990. Utilization of ileal digestible amino acids for growing pigs: Effect of dietary lysine concentration on efficiency of lysine retention. Br. J. Nutr. 64:81.

Batterham, E. S., and H. S. Bayley. 1989. Effect of frequency of feeding of diets containing free or protein-bound lysine on the oxidation of $\left[{ }^{14} \mathrm{C}\right]$ lysine or $\left[{ }^{14} \mathrm{C}\right]$ phenylalanine by growing pigs. Br. J. Nutr. 62:647.

Bikker, P., M. W. A. Verstegen, and S. Tamminga. 1994. Partitioning of dietary nitrogen between body components and waste in young growing pigs. Neth. J. Agric. Sci. 42:37.

Cai, Y., C. Richard, and D. Zimmerman. 1996. Effects of dietary protein and potassium contents on plasma urea nitrogen and amino acids in relation to performance in swine. Can. J. Anim. Sci. 76:351.

Campbell, R. G. 1977. The response of earlyweaned pigs to various protein levels in a high energy diet. Anim. Prod. 24:69.

Campbell, R. G., M. R. Taverner, and C. J. Rayner. 1988. The tissue and dietary protein and amino acid requirement of pigs from 8.0 to $20.0 \mathrm{~kg}$ live weight. Anim. Prod. 46:283.

Cosgrove, S. B., J. R. Corley, and D. C. Mahan. 1985. Effects of combining protein sources on lysine utilization by starter pigs. J. Anim. Sci. 60:470.

de Lange, C. F. M., S. H. Birkett, and P. C. H. Morel. 2001. Protein, fat, and bone tissue growth in swine. p. 65 in Swine Nutrition. A. 
J. Lewis and L. L. Southern, ed. CRC Press, New York, NY.

Easter, R. A., and D. H. Baker. 1980. Lysine and protein levels in corn-soybean meal diets for growing-finishing swine. J. Anim. Sci. 50:467.

Gahl, M. J., T. D. Crenshaw, and N. J. Benevenga. 1992. Amino acid composition and retention in growing pigs fed graded levels of lysine. J. Anim. Sci. 70(Suppl. 1):66. (Abstr.)

Gahl, M. J., T. D. Crenshaw, and N. J. Benevenga. 1994. Diminishing returns in weight, nitrogen, and lysine gain of pigs fed six levels of lysine from three supplemental sources. J. Anim. Sci. 72:3177.

Gómez, R. S., A. J. Lewis, P. S. Miller, H. Y. Chen, and R. M. Diedrichsen. 2002. Body composition and tissue accretion rates of barrows fed corn-soybean meal diets or lowprotein, amino acid-supplemented diets at different feeding levels. J. Anim. Sci. 80:654.

Han, K., and J. H. Lee. 2000. The role of synthetic amino acids in monogastric animal production. Asian-australas. J. Anim. Sci. 13:543.

Leibert, F. 1995. Results about lysine utilization in growing monogastric animals with special respect to different lysine sources. Arch. Anim. Nutr. 47:373.

Leibholz, J. 1986. The utilization of lysine by young pigs from nine protein concentrates compared with free lysine in young pigs. Br. J. Nutr. 55:179.
Lenis, N. P., H. T. M. van Diepen, P. Bikker, A. W. Jongbloed, and J. van der Meulen. 1999. Effect of the ratio between essential and nonessential amino acids in the diet on utilization of nitrogen and amino acids by growing pigs. J. Anim. Sci. 77:1777.

Mahan, D. C., and R. G. Shields Jr. 1998. Essential and nonessential amino acid composition of pigs from birth to 145 kilograms of body weight, and comparisons to other studies. J. Anim. Sci. 76:513.

Marsh, W. H., B. Fingerhut, and H. Miller. 1965. Automated and manual direct methods for the determination of blood urea. Clin. Chem. 11:624.

Mavromichalis, I., D. M. Webel, J. L. Emmert, R. L. Moser, and D. H. Baker. 1998 Limiting order amino acids in a low-protein corn-soybean meal-whey-based diet for nursery pigs. J. Anim. Sci. 76:2833.

Möhn, S., A. M. Gillis, P. J. Moughan, and C. F. de Lange. 2000. Influence of dietary lysine and energy intakes on body protein deposition and lysine utilization in the growing pigs. J. Anim. Sci. 78:1510

Moore, S., and W. Stein. 1963. Chromatographic determination of amino acids by the use of automatic recording equipment. Methods Enzymol. 6:819.

NRC. 1998. Nutrient Requirements of Swine. 10th ed. Natl. Acad. Press, Washington, DC.

Pollmann, D. S., G. L. Allee, M. E. Johnston, and R. H. Hines. 1984. Protein and lysine sources in starter pig diets. J. Anim. Sci. 59(Suppl. 1):248. (Abstr.)

Rosebrough, R. W., N. C. Steele, and J. P. McMurtry. 1983. Effect of protein level and supplemental lysine on growth and urea cycle enzyme activity in the pigs. Growth 47:348.

Sawadogo, M. L., A. Piva, A. Panciroli, E. Meola, A. Mordeni, and B. Séve. 1997. Marginal efficiency of free or protected crystalline L-tryptophan for tryptophan and protein accretion in early-weaned pigs. J. Anim. Sci. 75:1561.

Shields, R. G., Jr., D. C. Mahan, and P. L. Graham. 1983. Changes in swine body composition from birth to $145 \mathrm{~kg}$. J. Anim. Sci. 57:43.

Susenbeth, A., R. Scheneider, and K. H. Menke. 1991. The effect of protein-bound lysine versus free lysine on protein retention in growing pigs. p. 18 in Protein Metabolism and Nutrition. EAAP Publ. 59. NIAS, Foulum, Denmark.

Whittemore, C. T., H. M. Taylor, and R. Henderson. 1981. Chemical and dissected composition changes in weaned piglets. Anim. Prod. 32:203.

Yen, J. T., B. J. Kerr, R. A. Easter, and A. M. Parkhurst. 2004. Difference in rates of net portal absorption between crystalline and protein bound lysine and threonine in growing pigs fed once daily. J. Anim. Sci. 82:1079. 